\title{
Agrobacterium-mediated transformation of maize
}

\author{
Yuji Ishida, Yukoh Hiei \& Toshihiko Komari \\ Plant Innovation Center, Japan Tobacco Inc., 700 Higashibara, Iwata, Shizuoka 438-0802, Japan. Correspondence should be addressed to Y.I. (yuji.a.ishida@ims.jti.co.jp).
}

Published online 21 June 2007; doi:10.1038/nprot.2007.241

\begin{abstract}
Maize may be transformed very efficiently using Agrobacterium tumefaciens-mediated methods. The most critical factor in the transformation protocol is the co-cultivation of healthy immature embryos of the correct developmental stage with $A$. tumefaciens; the embryos should be collected only from vigorous plants grown in well-conditioned glasshouses. With the protocol described here, approximately $50 \%$ of immature embryos from the inbred line A188 and 15\% from inbred lines A634, H99 and W117 will produce transformants. About half of the transformed plants are expected to carry one or two copies of the transgenes, which are inherited by the progeny in a mendelian fashion. More than $90 \%$ of transformants are expected to be normal in morphology. The protocol takes about 3 months from the start of co-cultivation to the planting of transformants into pots.
\end{abstract}

\section{INTRODUCTION}

Transgenic maize plants were first obtained from protoplasts by an electroporation method ${ }^{1}$, but fertile plants have never been produced by this method. Other direct gene transfer methods, which did not require the prior culture of protoplasts, were then tried ${ }^{2-5}$, and microprojectile bombardment ${ }^{6}$ of cells in suspension cultures or immature embryos became quite popular in basic and applied studies. Efficiency of transformation by microprojectile bombardment has been higher than other direct methods, and quite a few fertile plants have been generated to date ${ }^{7}$. Microprojectile bombardment is also useful for the analysis of the transient expression of foreign genes in intact, fully developed tissues. However, high copy numbers and extensive rearrangement of the foreign DNA have frequently been found in plants transformed with direct gene transfer methods 8,9 .

For the last two decades, dicotyledonous plants have been transformed using the soil phytopathogen A. tumefaciens. A. tumefaciens is first transformed with the DNA construct of interest (T-DNA); this modified bacterial strain is then used to introduce the T-DNA into plants. A major advantage of Agrobacteriummediated transformation is that a small number of copies (often one or two) of relatively large segments (can be larger than $10 \mathrm{~kb}$ ) of T-DNA with defined ends are integrated into the plant genome with minimal rearrangement, resulting in transgenic plants of high quality. Initially, it was not clear if this technology could be extended to monocotyledonous plants, as they are not natural hosts of A. tumefaciens. However, a highly efficient method of transformation of rice by $A$. tumefaciens was reported ${ }^{10}$, followed by successful reports of the transformation of important cereals such as maize ${ }^{11}$, wheat ${ }^{12}$, barley $^{13}$ and sorghum ${ }^{14}$ by $A$. tumefaciens. Key factors in these achievements include the optimization of types of plant material for infection with A. tumefaciens, choice of vectors, choice of strains of $A$. tumefaciens and optimization of tissue culture techniques. Transformation mediated by A. tumefaciens is now highly recommended for maize varieties with good tissue culture responses.

For the successful production of transgenic plants in any species, foreign genes must be delivered to undifferentiated, dedifferentiated or dedifferentiating cells that are actively dividing or about to divide and that are capable of regenerating plants. In maize, the material of choice is immature embryos, and all protocols mediated by particle bombardment or A. tumefaciens for efficient production of transgenic maize have solely employed immature embryos. Thus, the primary determinants of a successful transformation are the response of immature embryos in tissue culture, the types of cells that grow from immature embryos and subsequent characteristics in growth and regeneration. Unfortunately, many genotypes of maize, especially so-called elite varieties, are poor in these aspects, and thus only a limited number of genotypes have been efficiently transformed so far.

In the original protocol of Ishida et al. ${ }^{11}$, transgenic plants were obtained from between $5 \%$ and $30 \%$ of A. tumefaciens-infected immature inbred A188 embryos. The protocol was successfully employed in a number of studies in molecular biology and biotechnology ${ }^{15-19}$. Since then, the methods have been greatly improved, and a highly optimized protocol routinely used in our laboratory is presented in this article ${ }^{20,21}$. An overview and typical timeline of this optimized protocol is given in Figure 1. The modifications made to the protocol include pretreatment by heat and centrifuging addition of silver and copper ions to the cocultivation medium and extension of the co-cultivation period from 3 to 7 days. The effects of heat, centrifuging and ions are evident $^{21}$, but the mechanisms are not understood. In protocols described by other authors, a resting culture, which is a nonselective incubation of embryos on a medium that contains an antibiotic to kill bacteria, is performed after co-cultivation ${ }^{22}$. In our experience, the growth of transformed cells was better in the selection culture if the resting culture was performed; however, the same effect was produced by an extended period of cocultivation. Thus, if the co-cultivation is extended, no resting culture is necessary. In general, the bar gene ${ }^{23}$, which confers resistance to the herbicide phosphinothricin, is a more effective selection agent than the $h p t$ gene ${ }^{24}$, which confers resistance to the antibiotic hygromycin. Further, use of vectors that carry additional virB and virG genes from pTiBo542 (see refs. 25,26) gives much higher transformation frequencies. The function of $\operatorname{vir} B$ is related to formation of a transmembrane channel between the bacterium and the plant cell and the function of virG is related to the activation of the other vir genes ${ }^{27}$.

Transgenic plants may be routinely obtained from more than $50 \%$ of the immature embryos from the A188 genotype, and the range of transformable genotypes has been extended to inbreds A634, H99 and W117 and hybrids between pairs of these varieties 
in our laboratory ${ }^{20,21}$. Hybrid genotype Hi-II (ref. 28) and inbreds Mo17, B104, B114 and Ky21 have been transformed by similar protocols in other laboratories ${ }^{22,29-31}$.

It should be noted that two types of embryogenic callus, type I and type II, may proliferate from the scutellum of immature embryos, depending on the genotypes of maize ${ }^{32}$. The type I callus is a relatively hard and compact embryogenic callus, whereas the type II callus is relatively soft and friable. A type I callus is usually obtained from inbreds A188, A634, H99 and W117 on the media described in this article. For genotypes such as Hi-II, from which the type II callus is frequently produced, modification of the media is recommended ${ }^{22,29,33}$. Protocols recommended for Hi-II and some other genotypes have been reported by other groups ${ }^{22,29-31}$. These protocols are similar to those presented in this article and differ essentially only in the composition of the media. While the macro components in all of the media in this article are based on the LS medium, those in the protocols of other groups are based mostly on the N6 medium. In addition, Frame et al. ${ }^{29}$ used media that contained cysteine for co-cultivation. Thus, especially when other genotypes are to be transformed, media based on N6 and media with cysteine should also be considered.

Elimination of selection marker genes from transgenic plants for commercialization is an important task because the presence of selection marker genes, which are unnecessary once transgenic plants are established, is of high public concern. A simple approach to remove selection markers is to perform A. tumefaciens-mediated co-transformation of plants with two T-DNA segments, one with a selection marker and the other with genes of interest, followed by segregation of marker-free progeny ${ }^{34}$. Because the frequency of cotransformants among initial transformants is never $100 \%$ and about a half of the co-transformants do not segregate marker-free progeny, this approach requires a high frequency of transformation, desirably more than 20\% (independent transgenics/immature embryo). With the highly optimized protocol presented here, production of marker-free transgenics has become a realistic option in maize; selection-marker-free transformants may be obtained from about $50 \%$ of co-transformed plants when co-transformation vectors are employed.

It is clear that the protocol presented in this article still needs to be improved. Despite the high frequency of transformation in A188 and related genotypes, the majority of genotypes-including the so-called elite inbreds-are not expected to be transformed

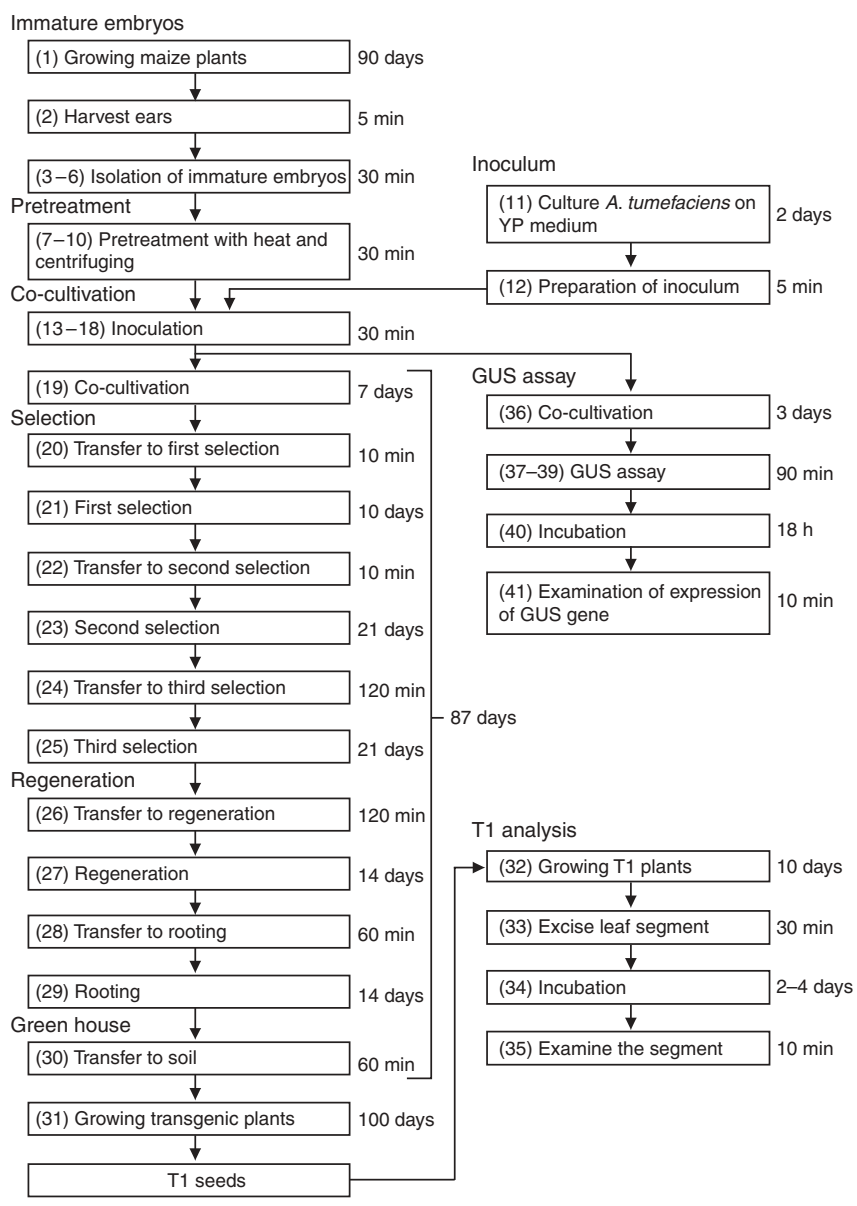

Figure 1 | Timeline of maize transformation protocol. It is assumed that 100 immature embryos are collected in Step 3 and that materials derived from the 100 embryos are handled in the subsequent steps by a single, skilled technician. Similarly, seeds from ten transgenic plants are examined in Steps $32-35$.

efficiently. In addition, there are many critical parameters in the protocol and the 'windows' of optimal conditions are very narrow; the assistance of an experienced tissue culture specialist may be necessary to establish and maintain efficient maize transformation programs.

\section{MATERIALS}

\section{REAGENTS}

- Maize seeds of inbreds A188, A634, H99 and W117 were supplied from the National Institute of Agrobiological Sciences of Japan

(http://www.nias.affrc.go.jp/index_e.html)

- A. tumefaciens strain carrying appropriate T-DNA-containing vectors

(see Table 1)

$\cdot 10 \times$ LS major salts (see REAGENT SETUP)

$\cdot 100 \times$ FeEDTA (see REAGENT SETUP)

$\cdot 100 \times$ LS minor salts (see REAGENT SETUP)

$\cdot 100 \times$ modified LS vitamins (see REAGENT SETUP)

- $100 \mathrm{mg} \mathrm{liter}^{-1}$ 2,4-dichlorophenoxy-acetic acid (2,4-D) (see REAGENT SETUP)

- $100 \mathrm{mg} \mathrm{liter}^{-1}$ Zeatin (see REAGENT SETUP)

$\cdot 100 \mathrm{mg} \mathrm{liter}^{-1}$ indole-3-butyric acid (IBA) (see REAGENT SETUP)

- $100 \mathrm{mg} \mathrm{liter}^{-1}$ 6-benzylamino-purine (6BA) (see REAGENT SETUP)

$\cdot 100 \mathrm{mM}$ acetosyringone (see REAGENT SETUP)
- 100 mM 5-bromo-4-chloro-3-indolyl $\beta$-D-glucuronide (X-gluc)

(see REAGENT SETUP)

. $50 \mathrm{mM} \mathrm{Na}_{2} \mathrm{HPO}_{4}$ (see REAGENT SETUP)

. $50 \mathrm{mM} \mathrm{NaH}_{2} \mathrm{PO}_{4}$ (see REAGENT SETUP)

- YP plates (see REAGENT SETUP)

- LS-inf medium (see REAGENT SETUP)

- LS-inf-AS medium (see REAGENT SETUP)

- LS-AS medium (see REAGENT SETUP)

- LSD1.5A medium (see REAGENT SETUP)

- LSD1.5B medium (see REAGENT SETUP)

- LSZ medium (see REAGENT SETUP)

- LSF medium (see REAGENT SETUP)

- ELA medium (see REAGENT SETUP)

- Soil for pots (see REAGENT SETUP)

- Buffer P, for $\beta$-glucuronidase (GUS) staining (see REAGENT SETUP and Box 1)

- Buffer X, for GUS staining (see REAGENT SETUP and Box 1) 
TABLE 1 | Typical frequency of transformation.

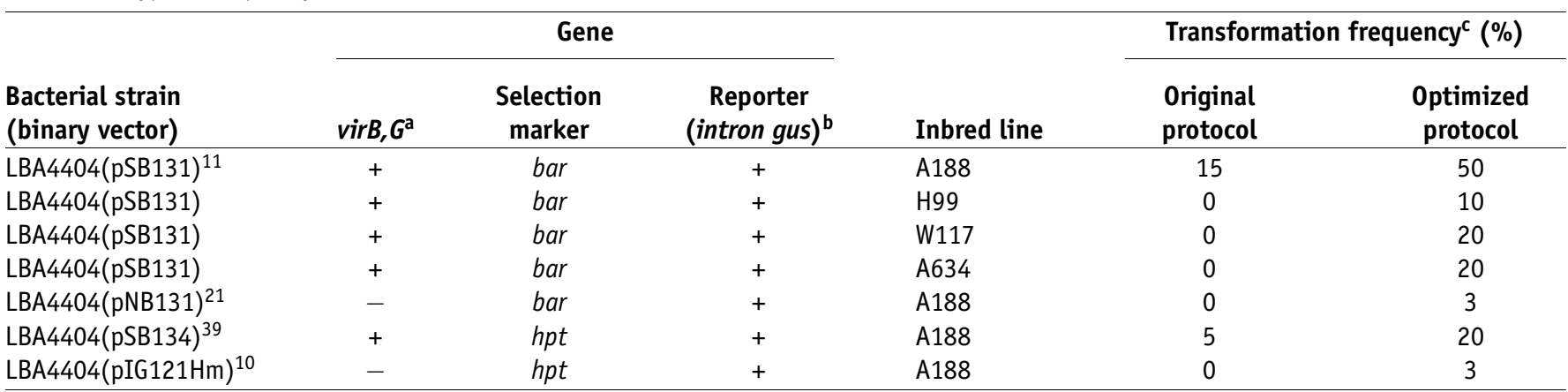

${ }_{+}+$: additional virB and virG from pTiBo542 (see refs. 25,26$)$. bintron gus: a $\beta$-glucuronidase (GUS) gene that carries an intron in the coding sequence (intron-gus ${ }^{40}$ ). ${ }^{~}$ Independent transgenic plants/inoculated immature embryos $\times 100$

\section{EQUIPMENT}

- Scalpel blade (no. 19, Futaba Co., Ltd)

-Surgical tape made of unwoven fabric (no. 25, Nichiban Co., Ltd, http://www.nichiban.co.jp/)

- Parafilm (Pechiney Plastic Packaging)

- $270 \mathrm{~mm}$ pot $(270 \mathrm{~mm}$ in diameter and $270 \mathrm{~mm}$ in height) for maize cultivation

- $230 \mathrm{~mm}$ pot (230 $\mathrm{mm}$ in diameter and $190 \mathrm{~mm}$ in height) for maize cultivation

REAGENT SETUP

10× LS major salts Dissolve $19.0 \mathrm{~g} \mathrm{KNO}_{3}, 16.5 \mathrm{~g} \mathrm{NH}_{4} \mathrm{NO}_{3}, 4.4 \mathrm{~g}$

$\mathrm{CaCl}_{2} \cdot 2 \mathrm{H}_{2} \mathrm{O}, 3.7 \mathrm{~g} \mathrm{MgSO}_{4} \cdot 7 \mathrm{H}_{2} \mathrm{O}$ and $1.7 \mathrm{~g} \mathrm{KH}_{2} \mathrm{PO}_{4}$ in $900 \mathrm{ml}$ distilled water and make up the volume to $1,000 \mathrm{ml}$ (see ref. 35). Store at $4{ }^{\circ} \mathrm{C}$. The final concentrations of components in this solution are $188 \mathrm{mM} \mathrm{KNO}_{3}, 206 \mathrm{mM}$ $\mathrm{NH}_{4} \mathrm{NO}_{3}, 30 \mathrm{mM} \mathrm{CaCl} \cdot 2 \mathrm{H}_{2} \mathrm{O}, 15 \mathrm{mM} \mathrm{MgSO}_{4} \cdot 7 \mathrm{H}_{2} \mathrm{O}$ and $12.5 \mathrm{mM} \mathrm{KH}_{2} \mathrm{PO}_{4}$ 100× FeEDTA Dissolve $2.78 \mathrm{~g} \mathrm{FeSO}_{4} \cdot 7 \mathrm{H}_{2} \mathrm{O}$ in $900 \mathrm{ml}$ of hot distilled water and add 3.73 g ethylenediamine- $N, N, N^{\prime}, N^{\prime}$-tetraaceticacid, disodium salt $\left(\mathrm{Na}_{2} \mathrm{EDTA}\right)$. Cool and make up the volume to $1,000 \mathrm{ml}$. Store at $4{ }^{\circ} \mathrm{C}$. The final concentrations of components in this solution are $10 \mathrm{mM} \mathrm{FeSO}{ }_{4} \cdot 7 \mathrm{H}_{2} \mathrm{O}$ and $10 \mathrm{mM} \mathrm{Na} 2 \mathrm{EDTA}$. $100 \times$ LS minor salts Dissolve $2.23 \mathrm{~g} \mathrm{MnSO}_{4} \cdot 5 \mathrm{H}_{2} \mathrm{O}, 1.06 \mathrm{~g} \mathrm{ZnSO}_{4} \cdot 7 \mathrm{H}_{2} \mathrm{O}$, $620 \mathrm{mg} \mathrm{H} \mathrm{BO}_{3}, 83 \mathrm{mg} \mathrm{KI}, 25.0 \mathrm{mg} \mathrm{Na} 2 \mathrm{MoO}_{4} \cdot 2 \mathrm{H}_{2} \mathrm{O}, 2.5 \mathrm{mg} \mathrm{CuSO} \mathrm{Cu}_{4} \cdot 5 \mathrm{H}_{2} \mathrm{O}$ and $2.5 \mathrm{mg} \mathrm{CoCl} \cdot 6 \mathrm{H}_{2} \mathrm{O}$ in $900 \mathrm{ml}$ of distilled water and make up the volume to $1,000 \mathrm{ml}$. Store at $4{ }^{\circ} \mathrm{C}$. The final concentrations of components in this solution are $9.3 \mathrm{mM} \mathrm{MnSO}_{4} \cdot 5 \mathrm{H}_{2} \mathrm{O}, 3.7 \mathrm{mM} \mathrm{ZnSO}_{4} \cdot 7 \mathrm{H}_{2} \mathrm{O}, 10 \mathrm{mM} \mathrm{H}_{3} \mathrm{BO}_{3}, 0.5 \mathrm{mM} \mathrm{KI}$, $0.1 \mathrm{mM} \mathrm{Na}_{2} \mathrm{MoO}_{4} \cdot 2 \mathrm{H}_{2} \mathrm{O}, 0.01 \mathrm{mM} \mathrm{CuSO}_{4} \cdot 5 \mathrm{H}_{2} \mathrm{O}$ and $0.01 \mathrm{mM} \mathrm{CoCl}_{2} \cdot 6 \mathrm{H}_{2} \mathrm{O}$. $100 \times$ modified LS vitamins Dissolve $10 \mathrm{~g}$ myoinositol, $100 \mathrm{mg}$ thiamine hydrochloride, $50 \mathrm{mg}$ pyridoxine hydrochloride and $50 \mathrm{mg}$ nicotinic acid in $900 \mathrm{ml}$ of distilled water and make up the volume to $1,000 \mathrm{ml}$. Store at $4{ }^{\circ} \mathrm{C}$. The final concentrations of components in this solution are $55.5 \mathrm{mM}$ myoinositol, $0.30 \mathrm{mM}$ thiamine hydrochloride, $0.24 \mathrm{mM}$ pyridoxine hydrochloride and 0.41 $\mathrm{mM}$ nicotinic acid.

$100 \mathrm{mg} \mathrm{liter}^{-1}$ 2,4-D Add $1 \mathrm{~N} \mathrm{NaOH}$ dropwise to $100 \mathrm{mg}$ 2,4-D until completely dissolved. Make up to $1,000 \mathrm{ml}$ with distilled water. Store at $4{ }^{\circ} \mathrm{C}$. The final concentration of 2,4-D in this solution is $0.45 \mathrm{mM}$.
$100 \mathrm{mg} \mathrm{liter}^{-1}$ zeatin Add $1 \mathrm{~N} \mathrm{NaOH}$ dropwise to $100 \mathrm{mg}$ zeatin until completely dissolved. Make up to $1,000 \mathrm{ml}$ with distilled water. Store at $4{ }^{\circ} \mathrm{C}$. The final concentration of zeatin in this solution is $0.46 \mathrm{mM}$

$100 \mathrm{mg} \mathrm{liter}^{-1}$ IBA Add $1 \mathrm{~N} \mathrm{NaOH}$ dropwise to $100 \mathrm{mg}$ IBA until completely dissolved. Make up to $1,000 \mathrm{ml}$ with distilled water. Store at $4{ }^{\circ} \mathrm{C}$. The final concentration of IBA in this solution is $0.49 \mathrm{mM}$.

$100 \mathrm{mg} \mathrm{liter}^{-1}$ 6BA Add $1 \mathrm{~N} \mathrm{NaOH}$ dropwise to $100 \mathrm{mg}$ 6BA until completely dissolved. Make up to $1,000 \mathrm{ml}$ with distilled water. Store at $4{ }^{\circ} \mathrm{C}$. The final concentration of $6 \mathrm{BA}$ in this solution is $0.44 \mathrm{mM}$.

$100 \mathrm{mM}$ acetosyringone Dissolve $392.4 \mathrm{mg}$ acetosyringone in $10 \mathrm{ml}$ of dimethyl sulfoxide and dilute with $10 \mathrm{ml}$ distilled water. Filter-sterilize and store in the dark at $4{ }^{\circ} \mathrm{C}$.

$100 \mathrm{mM} \mathrm{X}$-gluc Dissolve $52 \mathrm{mg} \mathrm{X}$-gluc (Sigma B6650) in $1 \mathrm{ml}$ of ethylene glycol monomethyl ether (Sigma E5378). Store in the dark at $-20{ }^{\circ} \mathrm{C}$.

! CAUTION Ethylene glycol monomethyl ether is toxic. Wear suitable protective clothing, gloves and eye/face protection.

$50 \mathbf{~ m M ~ N a}_{2} \mathbf{H P O}_{4}$ Dissolve $17.91 \mathrm{~g} \mathrm{Na}_{2} \mathrm{HPO}_{4} \cdot 12 \mathrm{H}_{2} \mathrm{O}$ in $900 \mathrm{ml}$ of distilled water and make up to $1,000 \mathrm{ml}$.

$50 \mathbf{~ m M ~ N a H}_{2} \mathrm{PO}_{4}$ Dissolve $7.8 \mathrm{~g} \mathrm{NaH}_{2} \mathrm{PO}_{4} \cdot 2 \mathrm{H}_{2} \mathrm{O}$ in $900 \mathrm{ml}$ of distilled water and make up to $1,000 \mathrm{ml}$.

YP plate (for A. tumefaciens) Dissolve $5 \mathrm{~g}$ yeast extract, $10 \mathrm{~g}$ peptone and $5 \mathrm{~g}$ sodium chloride in $900 \mathrm{ml}$ of distilled water and adjust $\mathrm{pH}$ to 6.8 with $\mathrm{NaOH}$.

Make up to $1,000 \mathrm{ml}$ and add $15 \mathrm{~g}$ agar (Difco). Autoclave at $121{ }^{\circ} \mathrm{C}$ for $15 \mathrm{~min}$. Cool the medium to $50{ }^{\circ} \mathrm{C}$, add appropriate antibiotics, which depend on the type of plasmid(s) in the strain, and pour $20 \mathrm{ml}$ aliquots into Petri dishes $(90 \times 15 \mathrm{~mm})$. LS-inf medium (for preparation of immature embryos) Add $100 \mathrm{ml}$ of $10 \times$ LS major salts, $10 \mathrm{ml}$ of $100 \times$ FeEDTA, $10 \mathrm{ml}$ of $100 \times$ LS minor salts, $10 \mathrm{ml}$ of $100 \times$ modified LS vitamins and $15 \mathrm{ml}$ of $100 \mathrm{mg}$ liter $^{-1}$ 2,4-D (final concentration is $1.5 \mathrm{mg} \mathrm{liter}^{-1}$ ) to $700 \mathrm{ml}$ of distilled water. Dissolve $68.46 \mathrm{~g}$ sucrose, $36.04 \mathrm{~g}$ glucose and $1.0 \mathrm{~g}$ Casamino acids in the mixture and make up the volume to $1,000 \mathrm{ml}$. Adjust $\mathrm{pH}$ to 5.2 and sterilize with a $0.22 \mu \mathrm{m}$ cellulose-acetate filter.

LS-inf-AS medium (for infection) Add $1 \mu \mathrm{l}$ of $100 \mathrm{mM}$ acetosyringone to $1 \mathrm{ml}$ of LS-inf medium.

\section{BOX 1 | EXAMINATION OF TRANSIENT EXPRESSION OF GUS AFTER CO-CULTIVATION (OPTIONAL FOR STRAINS THAT CARRY AN INTRON-GUS GENE)}

Monitoring of the level of expression of a transgene in the immature embryos gives very useful information for optimization of the protocol. The intron-gus gene ${ }^{40}$, in which there is an intron in the coding sequence of the $\beta$-glucuronidase $\left(\mathrm{GUS}^{41}\right)$, has been especially convenient because the presence of this gene does not result in the expression of GUS activity in Agrobacterium. As this is a destructive assay, the embryos examined in this method cannot be returned to the culture.

1. After Step 18, incubate the embryos in the dark at $25^{\circ} \mathrm{C}$ for 3 days.

2. After 3 days of inoculation, immerse the embryos in $0.5 \mathrm{ml}$ of buffer $\mathrm{P}$ in a microcentrifuge tube and incubate at $37{ }^{\circ} \mathrm{C}$ for $1 \mathrm{~h}$.

3. Remove the buffer and add $0.3 \mathrm{ml}$ of buffer $X$.

4. Place under mild vacuum (half an atmosphere) for $5 \mathrm{~min}$.

5. Incubate for $18 \mathrm{~h}$ at $37^{\circ} \mathrm{C}$.

6. Examine embryos for change in color under stereoscopic microscope. Figure 6 shows typical results of a GUS-staining experiment. 
LS-AS medium (for co-cultivation) Add $100 \mathrm{ml}$ of $10 \times$ LS major salts, $10 \mathrm{ml}$ of $100 \times$ FeEDTA, $10 \mathrm{ml}$ of $100 \times$ LS minor salts, $10 \mathrm{ml}$ of $100 \times$ modified LS vitamins, $15 \mathrm{ml}$ of $100 \mathrm{mg} \mathrm{liter}^{-1}$ 2,4-D (final concentration is $1.5 \mathrm{mg} \mathrm{liter}^{-1}$ ) and $0.05 \mathrm{ml}$ of $100 \mathrm{mM} \mathrm{CuSO}_{4}$ to $700 \mathrm{ml}$ of distilled water. Dissolve $20 \mathrm{~g}$ sucrose, $10 \mathrm{~g}$ glucose, $0.7 \mathrm{~g}$ proline and $0.5 \mathrm{~g}$ MES in the mixture and make up the volume to $1,000 \mathrm{ml}$. Adjust $\mathrm{pH}$ to 5.8 and add $8 \mathrm{~g}$ agarose. Autoclave and cool to $50{ }^{\circ} \mathrm{C}$, and add $1 \mathrm{ml}$ of $100 \mathrm{mM}$ acetosyringone and $0.05 \mathrm{ml}$ of $100 \mathrm{mM} \mathrm{AgNO}_{3}$ and pour $30 \mathrm{ml}$ aliquots into Petri dishes $(90 \times 20 \mathrm{~mm})$. Store in the dark at room temperature $\left(20-25{ }^{\circ} \mathrm{C}\right)$.

LSD1.5A medium (for first selection of transformed cells) Add $100 \mathrm{ml}$ of $10 \times$ LS major salts, $10 \mathrm{ml}$ of $100 \times$ FeEDTA, $10 \mathrm{ml}$ of $100 \times$ LS minor salts, $10 \mathrm{ml}$ of $100 \times$ modified LS vitamins and $15 \mathrm{ml}$ of $100 \mathrm{mg} \mathrm{liter}^{-1} 2,4-\mathrm{D}$ (final concentration is $1.5 \mathrm{mg} \mathrm{liter}^{-1}$ ) to $700 \mathrm{ml}$ of distilled water. Dissolve $20 \mathrm{~g}$ sucrose, $0.7 \mathrm{~g}$ proline and $0.5 \mathrm{~g}$ MES in the mixture and make up the volume to $1,000 \mathrm{ml}$. Adjust $\mathrm{pH}$ to 5.8 and add $8 \mathrm{~g}$ agar (Sigma, A6013-500G). Autoclave at $121^{\circ} \mathrm{C}$ for $15 \mathrm{~min}$. Cool to $50^{\circ} \mathrm{C}$ and add $1 \mathrm{ml}$ of $250 \mathrm{~g} \mathrm{liter}{ }^{-1}$ carbenicillin (final concentration is $250 \mathrm{mg} \mathrm{liter}^{-1}$ ), $0.4 \mathrm{ml}$ of $250 \mathrm{~g} \mathrm{liter}^{-1}$ cefotaxime (final concentration is $100 \mathrm{mg} \mathrm{liter}^{-1}$ ), $0.1 \mathrm{ml}$ of $100 \mathrm{mM} \mathrm{AgNO}_{3}$ and either $0.25 \mathrm{ml}$ of $20 \mathrm{~g} \mathrm{liter}^{-1}$ phosphinothricin (Riedel-de Haën AG) (final concentration is $5 \mathrm{mg}$ liter $^{-1}$ ) for bar selection or $0.3 \mathrm{ml}$ of $50 \mathrm{~g} \mathrm{liter}^{-1}$ hygromycin (Calbiochem) (final concentration is $15 \mathrm{mg} \mathrm{liter}^{-1}$ ) for $h p t$ selection. Pour $30 \mathrm{ml}$ aliquots into Petri dishes $(90 \times 20 \mathrm{~mm})$ and store in the dark at room temperature. LSD1.5B medium (for second and third selection of transformed cells) This is identical to LSD1.5A medium except for the amount of selective agent. Add $0.5 \mathrm{ml}$ of $20 \mathrm{~g} \mathrm{liter}^{-1}$ phosphinothricin (final concentration is $10 \mathrm{mg} \mathrm{liter}^{-1}$ ) instead of $0.25 \mathrm{ml}$ or $0.6 \mathrm{ml}$ of $50 \mathrm{~g}^{\text {liter }}{ }^{-1}$ hygromycin (final concentration is $30 \mathrm{mg}$ liter $^{-1}$ ) instead of $0.3 \mathrm{ml}$ in this case.

LSZ medium (for regeneration of transformed plants) Add $100 \mathrm{ml}$ of $10 \times \mathrm{LS}$ major salts, $10 \mathrm{ml}$ of $100 \times$ FeEDTA, $10 \mathrm{ml}$ of $100 \times$ LS minor salts, $10 \mathrm{ml}$ of $100 \times$ modified LS vitamins, $50 \mathrm{ml}$ of $100 \mathrm{mg} \mathrm{liter}^{-1}$ zeatin (final concentration is $5 \mathrm{mg} \mathrm{liter}{ }^{-1}$ ) and $0.1 \mathrm{ml}$ of $100 \mathrm{mM} \mathrm{CuSO}_{4}$ to $700 \mathrm{ml}$ of distilled water.

Dissolve $20 \mathrm{~g}$ sucrose and $0.5 \mathrm{~g}$ MES in the mixture and make up the volume to $1,000 \mathrm{ml}$. Adjust $\mathrm{pH}$ to 5.8 and add $8 \mathrm{~g}$ agar (Sigma, A6013-500G). Autoclave at
$121{ }^{\circ} \mathrm{C}$ for $15 \mathrm{~min}$. Cool to $50{ }^{\circ} \mathrm{C}$, and add $1 \mathrm{ml}$ of $250 \mathrm{~g} \mathrm{liter}^{-1}$ carbenicillin (final concentration is $250 \mathrm{mg} \mathrm{liter}^{-1}$ ), $0.4 \mathrm{ml}$ of $250 \mathrm{~g} \mathrm{liter}^{-1}$ cefotaxime (final concentration is $100 \mathrm{mg}$ liter ${ }^{-1}$ ) and either $0.25 \mathrm{ml}$ of $20 \mathrm{~g} \mathrm{liter}^{-1}$ phosphinothricin (final concentration is $5 \mathrm{mg} \mathrm{liter}^{-1}$ ) for bar selection or $0.6 \mathrm{ml}$ of $50 \mathrm{~g} \mathrm{liter}^{-1}$ hygromycin (final concentration is $30 \mathrm{mg} \mathrm{liter}^{-1}$ ) for $h p t$ selection. Pour $30 \mathrm{ml}$ aliquots into Petri dishes $(90 \times 20 \mathrm{~mm})$ and store in the dark at room temperature.

LSF medium (for rooting of transformed plants) Add $100 \mathrm{ml}$ of $10 \times$ LS major salts, $10 \mathrm{ml}$ of $100 \times$ FeEDTA, $10 \mathrm{ml}$ of $100 \times$ LS minor salts, $10 \mathrm{ml}$ of $100 \times$ modified LS vitamins and $2 \mathrm{ml}$ of $100 \mathrm{mg} \mathrm{liter}^{-1}$ IBA (final concentration in $0.2 \mathrm{mg} \mathrm{liter}^{-1}$ to $700 \mathrm{ml}$ of distilled water. Dissolve $15 \mathrm{~g}$ sucrose and $0.5 \mathrm{~g} \mathrm{MES} \mathrm{in}$ the mixture and make up the volume to $1,000 \mathrm{ml}$ and adjust $\mathrm{pH}$ to 5.8 . Add $3 \mathrm{~g}$ gellan gum and warm to $90{ }^{\circ} \mathrm{C}$ to dissolve. Pour $10 \mathrm{ml}$ aliquots to glass test tubes (25 mm in diameter $\times 100 \mathrm{~mm}$ in height). Cover the tubes with polypropylene caps and autoclave at $121{ }^{\circ} \mathrm{C}$ for $15 \mathrm{~min}$. Store at room temperature.

ELA medium (for detached leaf analysis) Add $100 \mathrm{ml}$ of $10 \times$ LS major salts, $10 \mathrm{ml}$ of $100 \times$ FeEDTA, $10 \mathrm{ml}$ of $100 \times$ LS minor salts and $5 \mathrm{ml}$ of $100 \mathrm{mg} \mathrm{liter}^{-1}$ 6BA (final concentration is $0.5 \mathrm{mg} \mathrm{liter}^{-1}$ ) to $700 \mathrm{ml}$ of distilled water. Dissolve $0.5 \mathrm{~g}$ MES in the mixture and make up the volume to $1,000 \mathrm{ml}$. Adjust $\mathrm{pH}$ to 5.8 and add $8 \mathrm{~g}$ agar (Sigma, A6013-500G). Autoclave at $121^{\circ} \mathrm{C}$ for $15 \mathrm{~min}$. Cool to $50{ }^{\circ} \mathrm{C}$ and add either $0.1 \mathrm{ml}$ of Basta (Bayer Crop Science) for analysis of expression of bar gene or $2 \mathrm{ml}$ of $50 \mathrm{mg} \mathrm{ml}^{-1}$ (final concentration is $100 \mathrm{mg}$ liter $^{-1}$ ) hygromycin for analysis of expression of $h p t$ gene. Pour $30 \mathrm{ml}$ aliquots into Petri dishes $(90 \times 20 \mathrm{~mm})$ and store in the dark at room temperature. Soil for pots A soil mixture for horticultural use that is commercially available and well drained is usually good. Adjust the major nutrients to $0.4 \mathrm{~g} \mathrm{~N}$ per liter, $0.4 \mathrm{~g} \mathrm{P}$ per liter and $0.4 \mathrm{~g} \mathrm{~K}$ per liter by adding a commercial fertilizer.

Buffer $\mathbf{P}$ Add $50 \mathrm{mM} \mathrm{Na} \mathrm{HPO}_{4}$ (about $500 \mathrm{ml}$ ) to $1,000 \mathrm{ml}$ of $50 \mathrm{mM}$ $\mathrm{NaH}_{2} \mathrm{PO}_{4}$ until the $\mathrm{pH}$ reaches 6.8. Sterilize using a $0.22 \mu \mathrm{m}$ cellulose-acetate filter and store at room temperature. Mix $9.9 \mathrm{ml}$ of this buffer and $0.1 \mathrm{ml}$ of Triton X-100 before use.

Buffer X Mix $8 \mathrm{ml}$ of buffer P, $0.1 \mathrm{ml}$ of $100 \mathrm{mM} \mathrm{X-gluc} \mathrm{and} 2 \mathrm{ml}$ methanol just before use.

\section{PROCEDURE}

\section{Preparation of immature embryos TIMING $\mathbf{3 5} \mathrm{min}$ for handling, $\mathbf{9 0}$ days for growing plants}

1| Grow maize plants in individual $270 \mathrm{~mm}$ pots in a greenhouse. Maintain daytime temperature between 30 and $35^{\circ} \mathrm{C}$ and night time temperature between 20 and $25^{\circ} \mathrm{C}$. Ideally, the light intensity should be stronger than $60,000 \mathrm{~lx}$ and the photoperiod should be more than $12 \mathrm{~h}$.

$\triangle$ CRITICAL STEP The quality of the immature embryos is one of the most import factors for achieving highly efficient maize transformation. Good embryos are obtained only from vigorous plants grown in a well-conditioned greenhouse. Air-conditioning and supplemental lights are needed to ensure a supply of good embryos year-round. Usually, more than 150 kernels can be collected from a single ear of A188. Production of a much lower number of kernels on a single cob implies that the growth conditions are not optimal. If transformation efficiency is poor, the greenhouse conditions should be optimized before investigating other aspects of the protocol, such as types of vectors and strains, and media compositions.

2| Between 8 and 15 days after pollination (DAP), harvest an ear that contains immature embryos at the right developmental stage (see Fig. 2).

$\triangle$ CRITICAL STEP The use of immature embryos at the right developmental stage is a critical factor, and the size of the embryos is a very good indicator of the stage. Immature embryos that are between 1.0 and $1.2 \mathrm{~mm}$ in length along the axis are optimal for transformation. Time (DAP) required for embryos to reach the best stage differs depending on the genotypes and the season. So carefully examine the sizes of embryos and determine the time of collection. A typical pattern of the growth of embryos is shown in Figure 2. For example, the time of collection for A188 was 8 DAP in August, 10 DAP in June and 15 DAP in January at our facility. As long as the sizes of embryos are in the above range, the frequency of transformation is reproducible year-round.

3| Husk the ear and detach kernels from the cob by cutting the base of the kernel with a scalpel (Fig. 3a,b). Insert a scalpel into the detached kernels (Fig. 3c) and remove the immature embryos (Fig. 3d). If plants are grown in a greenhouse free from disease and pest, cobs in husks are clean and immature embryos can be removed without surface sterilization of the cobs.

4) Immerse the embryos in $2.0 \mathrm{~mL}$ of LS-inf medium in a $2.0 \mathrm{~mL}$ microcentrifuge tube at room temperature until the remaining embryos have been collected. Finish the collection of immature embryos within $1 \mathrm{~h}$. More than 200 immature embryos can be collected in $1 \mathrm{~h}$ by a single, skilled technician.

5| Vortex the microcentrifuge tube at 2,700 r.p.m. at room temperature for $5 \mathrm{~s}$ and remove the medium. 


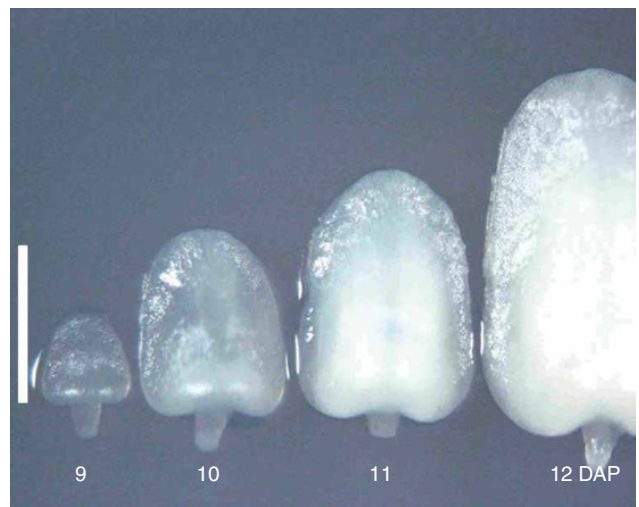

Figure 2 | Size of immature embryo. Immature embryos of 9-12 DAP were collected from maize inbred line A188 on June 2004 in Iwata, Shizuoka, Japan. Immature embryo of 10 DAP is $1.2 \mathrm{~mm}$ in length and suitable for transformation in this case. Scale bar, $1 \mathrm{~mm}$.
6| Add $2.0 \mathrm{ml}$ of LS-inf medium and vortex as in Step 5.

Pre-treatment with heat and centrifuging TIMING $\mathbf{3 0}$ min 7| Incubate the embryos in the microcentrifuge tube in a water bath at $46{ }^{\circ} \mathrm{C}$ for 3 min.

$\triangle$ CRITICAL STEP The optimal conditions for this heat treatment will differ depending on genotype. The conditions described here work well for genotypes A188, H99 and A634. Since immature embryos of W117 were more sensitive to heat than these genotypes, lower temperature and/or shorter treatment may be suitable for successful transformation in W117. Optimization will be necessary to find the best conditions for other strains and can be assessed by co-culturing with a strain of A. tumefaciens carrying an intron-GUS gene (Steps 11-13) and GUS staining at Step 18 (see Box 1). In addition, it is also important to assess callus induction from heat-treated immature embryos.

8| Cool the microcentrifuge tube on ice for $1 \mathrm{~min}$.

9| Remove the medium and add $2.0 \mathrm{ml}$ of LS-inf medium.

10| Centrifuge the microcentrifuge tube with a fixed-angle rotor with a maximum radius of $83 \mathrm{~mm}$ at $20,000 \mathrm{~g}$ at $4{ }^{\circ} \mathrm{C}$ for $10 \mathrm{~min}$.

$\triangle$ CRITICAL STEP The optimal centrifugation conditions will differ depending on genotype. The conditions described here work well for genotypes A188, A634, W117 and H99. Optimization will be necessary to find the best conditions for other strains and can be assessed by co-culturing with a strain of $A$. tumefaciens carrying an intron-GUS gene (Steps 11-13) and GUS staining at Step 18 (see Box 1).

\section{Preparation of inoculum TIMING 5 min for handling, 2 days for cultivation}

11| Culture A. tumefaciens strain on a YP plate that contains appropriate antibiotics in the dark at $28{ }^{\circ} \mathrm{C}$ for 2 days.

12 Collect the bacteria with a loop and suspend in $1.0 \mathrm{~mL}$ of LS-inf-AS medium at a density of $1 \times 10^{9}$ colony-forming units per $\mathrm{ml}(\mathrm{OD}=1.0$ at $660 \mathrm{~nm})$. Inoculum should be prepared fresh. Growth of Agrobacterium in liquid culture before transformation is not necessary.

\section{Inoculation and co-cultivation TIMING $\mathbf{3 0}$ min for handling, $\mathbf{7}$ days for cultivation}

13| Remove the medium from the microcentrifuge tube in Step 10 and add $1.0 \mathrm{ml}$ of bacterial suspension from Step 12.

14| Vortex the microcentrifuge tube at 2,700 r.p.m. for $30 \mathrm{~s}$.

15| Incubate for $5 \mathrm{~min}$ at room temperature.

16| Transfer the suspension of the embryos and bacteria to an empty Petri dish $(60 \times 15 \mathrm{~mm})$.

17| Remove and discard $0.7 \mathrm{ml}$ of the liquid from the suspension.

18| Transfer the embryos onto fresh LS-AS solid medium with the scutellum face up and seal the Petri dishes with Parafilm. Up to 200 embryos may be placed on a single plate. If the procedure is being optimized using strains that contain the intron-gus gene, transient expression of GUS can be analyzed at this point, as detailed in Box 1.

19| Incubate in the dark at $25^{\circ} \mathrm{C}$ for 7 days; this is the co-cultivation step.
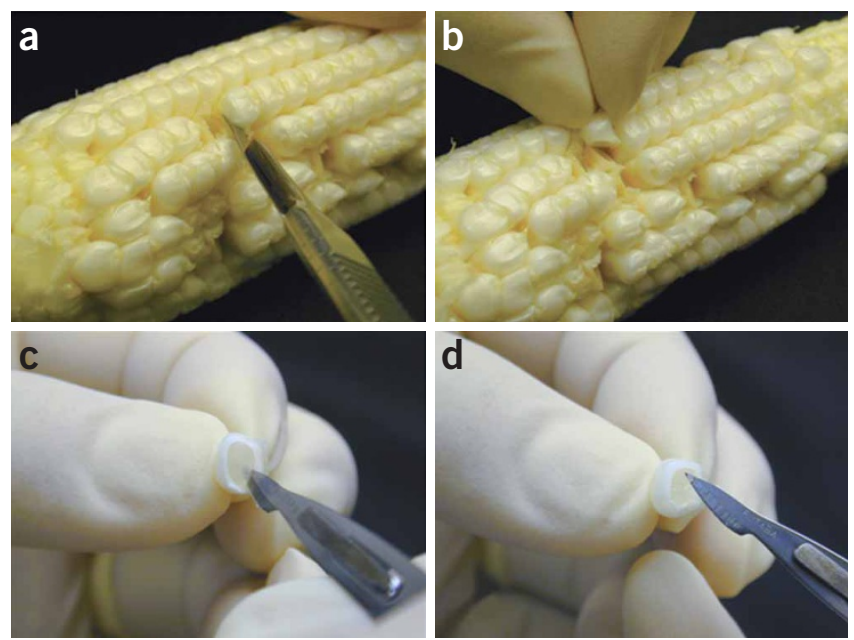

Figure 3 | Isolation of immature embryo. (a) Cut a kernel; (b) take out the kernel; (c) insert a scalpel into the kernel; and (d) lift out an immature embryo. 


\section{Selection of transformed calli $\bigcirc$ TIMING $\mathbf{1 4 0}$ min for handling, 52 days for cultivation}

20| Transfer the embryos to LSD1.5A medium and seal the Petri dishes with surgical tape. Up to 25 embryos may be placed on a single plate.

$\triangle$ CRITICAL STEP Do not rinse the embryos. Rinsing with an antibiotic solution tends to result in poor growth of cells. The surgical tape, which allows aeration, is much better for the growth of plant cells than air-tight tapes.

21 Incubate in the dark at $25^{\circ} \mathrm{C}$ for 10 days; this is the first selection.

22| Transfer the embryos to LSD1.5B medium, and seal the Petri dishes with surgical tape. Up to 25 embryos may be placed on a single plate.

23. Incubate in the dark at $25^{\circ} \mathrm{C}$ for 21 days; this is the second selection.

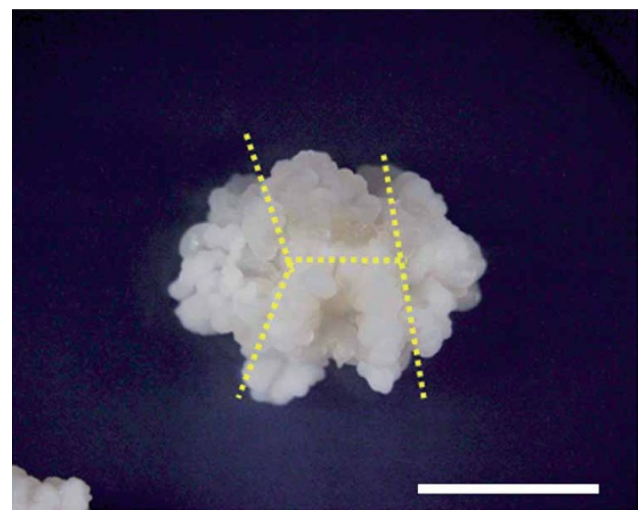

Figure 4 | Guide to cutting type I callus for third selection and regeneration step. Proliferated type I callus is cut with a scalpel as indicated by yellow dotted lines. The size of the cut fragment is 3-5 $\mathrm{mm}$ at Step 24 or 2-3 $\mathrm{mm}$ at Step 26. Scale bar, $5 \mathrm{~mm}$.

24| Cut type I calli proliferated from the scutellum into pieces of between 3 and $5 \mathrm{~mm}$ in diameter under a stereoscopic microscope (Fig. 4), transfer to LSD1.5B medium and seal the Petri dishes with the surgical tape. Up to 25 pieces may be placed on a single plate.

25 Incubate in the dark at $25^{\circ} \mathrm{C}$ for 21 days; this is the third selection. Proliferated type I calli are transgenic.

Regeneration of transformed plants TIMING $\mathbf{2 4 0}$ min for handling, 28 days for cultivation, 100 days for growing plants 26| Cut the further proliferated type I calli from Step 25 into pieces of between 2 and $3 \mathrm{~mm}$ in diameter under a stereoscopic microscope, transfer to LSZ medium and seal the Petri dishes with Parafilm. Up to 25 pieces may be placed on a single plate.

27| Incubate under continuous illumination $(5,000 \mathrm{~lx})$ at $25^{\circ} \mathrm{C}$ for 14 days.

28| Transfer a regenerated shoot to a tube of LSF medium, and cover with a polypropylene cap.

29| Incubate under continuous illumination $(5,000 \mathrm{~lx})$ at $25^{\circ} \mathrm{C}$ for 14 days.

30| Transfer each plant to a $230 \mathrm{~mm}$ pot containing appropriately supplemented soil (see REAGENT SETUP).

31 Grow transgenic plants in a greenhouse as detailed in Step 1 for 3-4 months and harvest progeny seeds. Plants in the following generations may be grown as detailed in Step 1.

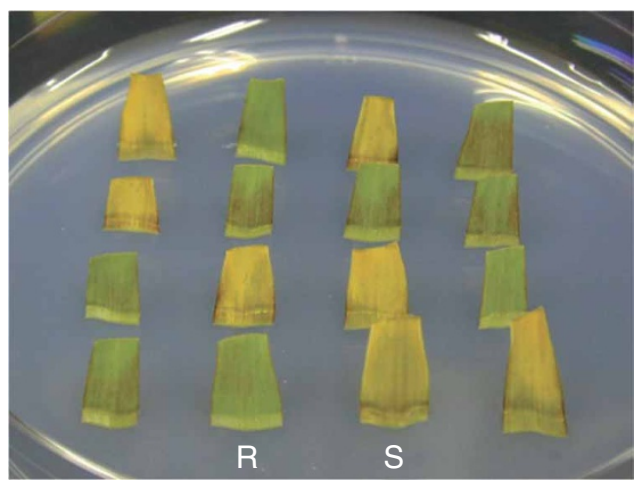

Figure 5 | Assay of segregation of transgene in detached leaves. Leaves are excised from T1 plants of inbred line A188 transformed with LBA4404 (pSB131). Detached leaves are inserted in the medium containing $0.1 \%(\mathrm{w} / \mathrm{v})$ Basta. The plate is incubated under continuous light at $25^{\circ} \mathrm{C}$ for 3 days. Green leaves are resistant to Basta (R) and therefore transgenic, whereas yellow leaves are sensitive to Basta $(S)$ and non-transgenic.
Examination of progeny for expression of a selection marker gene TIMING 10 days for growing plants, $\mathbf{3 0}$ min for handling, 2-4 days for incubation, $10 \mathrm{~min}$ for examination 32| This examination is performed by the modified method of Wang and Waterhouse ${ }^{36}$. Sow individual progeny seeds of transgenic plants in soil in $40 \mathrm{~mm} \times 40 \mathrm{~mm}$ plastic pots and grow as detailed in Step 1. It is preferable that more than 30 seeds are sown and examined.

33| Excise a leaf segment of $10 \mathrm{~mm}$ in length from a 10-day-old seedling, insert $3 \mathrm{~mm}$ of the tip of the segment in ELA medium, and seal the Petri dish with Parafilm.

34| Incubate the plates under constant illumination $(5,000 \mathrm{~lx})$ at $25^{\circ} \mathrm{C}$.

35| Examine the segment for changes in the color 2, 3 and 4 days after the start of incubation. A resistant segment, which 
expresses the transgene, stays green whereas a sensitive segment (non-transgenic) turns yellow (Fig. 5).

? TROUBLESHOOTING

\section{TIMING}

A typical timeline for the optimized protocol is given in

Figure 1. It takes 87 days from the start of co-cultivation

(Step 19) to the planting of transformants into soil in pots (Step 30).

\section{? TROUBLESHOOTING}

If transformation is unsuccessful and no transformants are obtained, ensure that the composition of all solutions and media is as indicated and perform all of the tissue culture steps without $A$. tumefaciens. Calli must grow vigorously from the immature embryos, and plants must be readily regenerated from the callus. Otherwise, ask an experienced maize breeder to examine the appearance of plants, temperature and light conditions of the greenhouse, soil conditions, watering frequency, etc. Take measures recommended by the expert. Check again if the sizes of the immature embryos are in the right range. If callus growth and plant regeneration without infection is fine, use an $A$. tumefaciens strain that carries the intron-gus gene to perform transient expression experiments (see Box 1). Typical results of this experiment are shown in Figure 6. If GUS expression is too low or too high, no transformants will be obtained. Adjust the concentration of $A$. tumefaciens, temperature and duration of heat treatment and centrifugal force and duration of centrifuging so that the expression is at the right level.

\section{ANTICIPATED RESULTS}

Typical average transformation frequencies for a number of maize genotypes are shown in Table 1 and raw data of transformation frequencies from a series of actual experiments are shown in Table 2. The optimized protocol has improved the frequency of transformation several fold over the original protocol for both selective markers, the bar gene and the $h p t$ gene. In addition, some of the genotypes that could not be transformed using the original protocol have been successfully transformed using the optimized protocol (see Table 1).

TABLE 2 | Frequency of transformation (raw data).

\begin{tabular}{|c|c|c|c|c|c|c|c|}
\hline Inbred line & Construct & $46^{\circ} \mathrm{C}$ (min) & $\begin{array}{c}\text { Inoculated } \\
\text { immature } \\
\text { embryos (A) }\end{array}$ & $\begin{array}{l}\text { Antibiotic- } \\
\text { resistant plants } \\
\text { produced (B) }\end{array}$ & $\begin{array}{c}\text { Frequency } \\
\text { of regeneration } \\
(B / A, \%)\end{array}$ & $\begin{array}{l}\text { Antibiotic-resistant, } \\
\text { GUS-positive plants } \\
\text { produced (C) }\end{array}$ & $\begin{array}{c}\text { Frequency of } \\
\text { transformation } \\
(\mathrm{C} / \mathrm{A}, \%)\end{array}$ \\
\hline A188 & pSB131 & 3 & 29 & 20 & 69.0 & 15 & 51.7 \\
\hline H99 & pSB131 & 3 & 38 & 3 & 7.9 & 3 & 7.9 \\
\hline W117 & pSB131 & 1.5 & 79 & 18 & 22.8 & 15 & 19.0 \\
\hline W117 & pSB131 & 2.5 & 74 & 30 & 40.5 & 20 & 27.0 \\
\hline A634 & pSB131 & 3 & 29 & 7 & 24.1 & 7 & 24.1 \\
\hline
\end{tabular}

All immature embryos were pretreated with centrifuging at $20,000 \mathrm{~g}$ for $10 \mathrm{~min}$.

To date, more than $90 \%$ of the maize plants transformed by $A$. tumefaciens have been normal in morphology and fertile ${ }^{11,20,21}$. About half of them had one or two copies of the transgenes. The other half had more than three copies of the transgene, but a majority of them had less than six copies ${ }^{11}$. Clear mendelian inheritance of the transgenes was observed in most of the cases ${ }^{11}$.

Co-transformation vectors ${ }^{34}$ have been tested in maize ${ }^{37,38}$. About half of the transformants carried the nonselective T-DNA, and selection marker-free transformants with solely the nonselective T-DNA were obtained from about half of these co-transformants. Thus, marker-free transformants may be segregated from a quarter of the transformants. With the highly optimized protocol, co-transformation processes may be performed very efficiently. 
ACKNOWLEDGMENTS We thank Ms. E. Usami and Ms. M. Noguchi for skillful assistance.

COMPETING INTERESTS STATEMENT The authors declare no competing financial interests.

Published online at http://www.natureprotocols.com

Rights and permissions information is available online at http://npg.nature.com/ reprintsandpermissions

1. Rhodes, C.A., Pierce, D.A., Mettler, I.J., Mascarenhas, D. \& Detmer, J.J. Genetically transformed maize plants from protoplasts. Science 240, 204-207 (1988).

2. Gordon-Kamm, W. et al. Transformation of maize cells and regeneration of fertile transgenic plants. Plant Cell 2, 603-618 (1990).

3. Fromm, M.E. et al. Inheritance and expression of chimeric genes in the progeny of transgenic maize plants. Biotechnology 8, 833-839 (1990).

4. D'Halluin, K., Bonne, K., Bossut, M., De Beuckeleer, M. \& Leemans, J. Transgenic maize plants by tissue electroporation. Plant Cell 4, 1495-1505 (1992).

5. Frame, B.R. et al. Production of fertile transgenic maize plants by silicon carbide whisker-mediated transformation. Plant J. 6, 941-948 (1994).

6. Koziel, M.G. et al. Field performance of elite transgenic maize plants expressing an insecticidal protein derived from Bacillus thuringiensis. Biotechnology 11, 194-200 (1993).

7. Armstrong, $C$. The first decade of maize transformation: a review and future perspective. Maydica 44, 101-109 (1999).

8. Register, J.C. III et al. Structure and function of selectable and non-selectable transgenes in maize after introduction by particle bombardment. Plant Mol. Biol. 25, 951-961 (1994).

9. Shou, H., Frame, B.A., Whitham, S.A. \& Wang, K. Assessment of transgenic maize events produced by particle bombardment or Agrobacterium-mediated transformation. Mol. Breed. 13, 201-208 (2004).

10. Hiei, Y., Ohta, S., Komari, T. \& Kumashiro, T. Efficient transformation of rice (Oryza sativa L.) mediated by Agrobacterium and sequence analysis of the boundaries of the T-DNA. Plant J. 6, 271-282 (1994).

11. Ishida, Y. et al. High efficiency transformation of maize (Zea mays L.) mediated by Agrobacterium tumefaciens. Nat. Biotechnol. 14, 745-750 (1996).

12. Cheng, M. et al. Genetic transformation of wheat mediated by Agrobacterium tumefaciens. Plant Physiol. 115, 971-980 (1997).

13. Tingay, S. et al. Agrobacterium tumefaciens-mediated barley transformation. Plant J. 11, 1369-1376 (1997).

14. Zhao, Z.-y. et al. Agrobacterium-mediated sorghum transformation. Plant Mol. Biol. 44, 789-798 (2000).

15. Negrotto, D., Jolley, M., Beer, S., Wenck, A.R. \& Hansen, G. The use of phosphomannose-isomerase as a selectable marker to recover transgenic maize plants (Zea mays L.) via Agrobacterium transformation. Plant Cell Rep. 19, 798-803 (2000).

16. Nomura, M. et al. The evolution of C4 plants: acquisition of cis-regulatory sequences in the promoter of C4-type pyruvate, orthophosphate dikinase gene. Plant J. 22, 211-221 (2000).

17. Ohta, S., Ishida, Y. \& Usami, S. Expression of cold-tolerant pyruvate, orthophosphate dikinase cDNA, and heterotetramer formation in transgenic maize plants. Transgenic Res. 13, 475-485 (2004).

18. Ohta, S., Ishida, Y. \& Usami, S. High-level expression of cold-tolerant pyruvate, orthophosphate dikinase from a genomic clone with site-directed mutations in transgenic maize. Mol. Breed. 18, 29-38 (2006).

19. Taniguchi, M. et al. The promoter for the maize C4 pyruvate, orthophosphate dikinase gene directs cell- and tissue-specific transcription in transgenic maize plants. Plant Cell Physiol. 41, 42-48 (2000).
20. Ishida, Y., Saito, H., Hiei, Y. \& Komari, T. Improved protocol for transformation of maize (Zea mays L.) mediated by Agrobacterium tumefaciens. Plant Biotechnol. 20, 57-66 (2003).

21. Hiei, Y., Ishida, Y., Kasaoka, K. \& Komari, T. Improved frequency of transformation in rice and maize by treatment of immature embryos with centrifugation and heat prior to infection with Agrobacterium tumefaciens. Plant Cell Tissue Organ Cult. 87, 233-243 (2006).

22. Zhao, Z.-y. et al. High throughput genetic transformation mediated by Agrobacterium tumefaciens in maize. Mol. Breed. 8, 323-333 (2001).

23. De Block, M. et al. Engineering herbicide resistance in plants by expressing of a detoxifying enzyme. EMBO J. 6, 2513-2518 (1987).

24. van den Elzen, P.J.M., Townsend, J., Lee, K.Y. \& Bedbrook, J.R. A chimaeric hygromycin resistance gene as a selectable marker in plant cells. Plant Mol. Biol 5, 299-302 (1985)

25. Hood, E.E. et al. Restriction endonuclease map of pTiBo542, a potential Ti-plasmid vector for genetic engineering of plants. Biotechnology 2 , 702-709 (1984)

26. Komari, T., Halperin, W. \& Nester, E.W. Physical and functional map of supervirulent Agrobacterium tumefaciens tumor-inducing plasmid pTiBo542. J. Bacteriol. 166, 88-94 (1986).

27. Sheng, J. \& Citovsky, V. Agrobacterium-plant cell DNA transport: have virulence proteins, will travel. Plant Cell 8, 1699-1710 (1996).

28. Armstrong, C.L., Green, C.E. \& Phillips, R.L. Development and availability of germplasm with high type II culture formation response. Maize Genet. Coop. News Lett. 65, 92-93 (1991).

29. Frame, B.R. et al. Agrobacterium tumefaciens-mediated transformation of maize embryos using a standard binary vector system. Plant Physiol. 129, 13-22 (2002).

30. Huang, X. \& Wei, Z. Successful Agrobacterium-mediated genetic transformation of maize elite inbred lines. Plant Cell Tissue Organ Cult. 83, 187-200 (2005).

31. Frame, B.R. et al. Improved Agrobacterium-mediated transformation of three maize inbred lines using MS salts. Plant Cell Rep. 25, 1024-1034 (2006).

32. Bajaj, Y.P.S. in Biotechnology in Agriculture and Forestry (ed. Bajaj, Y.P.S.) 3-23 (Springer-Verlag, Berlin, Heidelberg, 1994).

33. Frame, B.R., Paque, T. \& Wang, K. in Methods in Molecular Biology (ed. Wang, K.) 185-199 (Humana Press Inc., Totowa, NJ, 2006).

34. Komari, T., Hiei, Y., Saito, Y., Murai, N. \& Kumashiro, T. Vectors carrying two separate T-DNAs for co-transformation of higher plants mediated by Agrobacterium tumefaciens and segregation of transformants free from selection markers. Plant J. 10, 165-174 (1996).

35. Linsmaier, E. \& Skoog, F. Organic growth factor requirements of tobacco tissue culture. Physiol. Plant 18, 100-127 (1965).

36. Wang, M.-B. \& Waterhouse, P.M. A rapid and simple method of assaying plants transformed with hygromycin and PPT resistance genes. Plant Mol. Biol. Rep. 15 209-215 (1997).

37. Miller, M. et al. High efficiency transgene segregation in co-transformation maize plants using an Agrobacterium tumefaciens 2 T-DNA binary system. Transgenic Res. 11, 381-396 (2002).

38. Ishida, Y. et al. Improved co-transformation of maize with vectors carrying two separate T-DNAs mediated by Agrobacterium tumefaciens. Plant Biotechnol. 21, 57-63 (2004).

39. Hiei, Y. \& Komari, T. Improved protocols for transformation of indica rice mediated by Agrobacterium tumefaciens. Plant Cell Tissue Organ Cult. 85, 271-283 (2006).

40. Ohta, S., Mita, S., Hattori, T. \& Nakamura, K. Construction and expression in tobacco of a $\beta$-glucuronidase (GUS) reporter gene containing an intron within the coding sequence. Plant Cell Physiol. 31, 805-813 (1990).

41. Jefferson, R.A. Assaying chimeric genes in plants: the GUS gene fusion system. Plant Mol. Biol. Rep. 5, 387-405 (1987). 